Swarthmore College

Works

\title{
Telling Wonders: Ethnographic And Political Discourse In The Work Of Herodotus
}

\author{
Rosaria Vignolo Munson \\ Swarthmore College, rmunson1@swarthmore.edu
}

Follow this and additional works at: https://works.swarthmore.edu/fac-classics

Part of the Classics Commons

\section{Recommended Citation}

Rosaria Vignolo Munson. (2001). "Telling Wonders: Ethnographic And Political Discourse In The Work Of Herodotus". Telling Wonders: Ethnographic And Political Discourse In The Work Of Herodotus. https://works.swarthmore.edu/fac-classics/39

This work is brought to you for free by Swarthmore College Libraries' Works. It has been accepted for inclusion in Classics Faculty Works by an authorized administrator of Works. For more information, please contact myworks@swarthmore.edu. 


\section{Introduction}

But the greatest wonder to me of all in that region, at least after the city itself, I am going to describe. It is their boats that go down the river to Babylon, all round and made of leather. For in the country of the Armenians, who live above the Assyrians, they cut ribs of willow and stretch around them watertight hides from the outside to serve as bottom, without broadening the stern or shaping the prow, but making it round like a shield. Then they fill this boat with straw, and after loading on the cargo, they launch it so that it is carried downstream. They mostly carry palmwood casks full of wine. The boat is steered by two paddles and two men standing up. One draws his paddle in and the other pushes his outward. These boats are made very large or of smaller size. The largest bear a cargo of up to five thousand talents. In each boat there is one live donkey, more if the boat is bigger. After they arrive by boat to Babylon and sell their cargo, they then auction off the frame and all the straw, but the hides they load on the donkeys and drive back to Armenia. For it is not in any way possible to sail upstream, because of the rapids of the river. For this reason, they make their boat not of wood but of leather. After they return to Armenia driving their donkeys, they make other boats in the same way. These are the boats they have. (Herodotus 1.194)

\section{The Problem of the Ethnographies Reformulated}

In 490 and 480 в.с., the Greek city-states managed to defeat the aggression of the autocratically ruled Persians. Herodotus' account of those events two generations later proceeds from the conflict's remote antecedents. It describes the rise and expansion of the Persian Empire until the time when, in the plenitude of its resources, it came to threaten the Greeks. But Herodotus' "story" also includes minute ethnographic descriptions, whose reason for being appears less plausible. For decades, we have read the Histories with the assumption, more or less resisted but 
never entirely defeated, that the ethnographies belonged to another project, not only deriving from a different tradition of prose writing, but also conceived at a different stage of the author's career and with different aims and concerns, a project whose disiecta membra were artfully but somewhat pointlessly inserted into the historical narrative. ${ }^{1}$ The lists of customs and geographical features in the ethnographies only occasionally provide information we need for our factual understanding of changes of dynasty and campaigns. We have come to agree that though they enrich the history in some general sense, they are not fully integrated with it.

We have recourse to several strategies for dealing with the issue of "unity" in Herodotus. The stylistic and conceptual analysis of Greek archaic literature in general has taught us not to apply our post-Platonic notions of unity to earlier works. ${ }^{2}$ We also do not, especially in our present interdisciplinary generation, regard ancient Greek ethnography and history as formally separate fields. Modern literary criticism outside the classics, for its part, has abandoned the requirement of coherence in a text; we now revel in its inconsistencies, contradictions, and omissions. ${ }^{3}$ But the fact remains that the ancient modes of discourse of history and ethnography, as these genres are combined in Herodotus' work, are objectively different. The one diachronically recounts unique events of the past and relies on chronological and causal continuity; the other synchronically describes permanent conditions and customary actions in the present in a discontinuous catalogue form. We are always bound to seek, therefore, a better understanding of their mutual cooperation and of the substantial connection between their respective aims.

So far, the best solution of all has come from those who have broadened Herodotus' subject matter almost ad infinitum. They have attributed the diversity of his material to his attempt to explain the human

1. Jacoby $(1913,281-362$, especially $327-34,341-55)$ attributes the genesis of the work to a conglomeration of originally independent logoi; the ethnographic logoi were composed earlier and have been integrated into a historical context with little modification. For a later developmental view, see von Fritz 1936. The unitarians either reject the notion of development and advocate Herodotus' adherence to an original plan (see, e.g., Lattimore 1958) or focus on the conceptual unity of the work as we have it. See especially Pohlenz 1937, on the assumptions of which the work of both Immerwahr (1966) and Lateiner (1989) is based. The integration of the ethnographic logo $i$ and other digressions in Herodotus is discussed by Cobet (1971), who also provides excellent surveys on unitarians and separatists $(1-44,188-98)$.

2. See Fränkel 1924; Van Groningen 1958. Cf. Pohlenz 1937, 67-87. On the history of the notion of literary unity in ancient Greek practice and criticism, see Ford 1990.

3. See Belsey 1980, 109. 
condition in a global way and with whatever evidence was available to a prose writer. ${ }^{4}$ This is too vague a recognition, however, for it does not eliminate the notion that Herodotus has lingered along the way of a goaldirected narrative-leading to his account of the Persian Wars-to include many items of information just "interesting for their own sake." 5 The problem of unity in the Histories, in other words, is strictly connected with that of their purpose. We should approach both issues by asking, What is the basic relation between the ideological position that emerges from Herodotus' history of the conflict with the other and that which he transmits through his description of multiple others?

My representation of what the Histories communicate to their intended audience is especially indebted to two very different but mutually complementary insights of recent scholarship. The first of these has been most lucidly formulated by Fornara as a general principle and through specific illustrations from Herodotus' narrative. Herodotus wrote and composed his history of the Persian Wars over a period of time in the 440 s, the 430 s, and perhaps even the 420 s and later: these are the years of Athenian imperialism, ever more threatening and oppressive to some of the Greeks before and during the first stage of the so-called great Peloponnesian War against Sparta and her allies. ${ }^{6}$ Herodotus' perspective is therefore comparable, for example, to that of an author writing about World War I in the course of World War II. ${ }^{7}$ His view of the past is bound to be

4. According to Immerwahr $(1966,5)$, Herodotus "first discovered history as a method of understanding the world as a whole." Cf. Cobet 1971, 177-87. Lateiner $(1989,16)$ suggests a richer and more specific set of answers when he asserts that "ethnographic information in the Histories . . . is documentation deployed to assert an historical thesis, namely that mankind has benefited from ethnic and political separation and self-determination."

5. The most radical denial of purposefulness in Herodotus comes from Howald ( 1923, 1944), but see also Fränkel 1924, especially 87 . The notion that something in Herodotus may be there simply because "it is itself worth reporting" in some obvious but unspecified way is still pervasive in some of the best Herodotean scholarship: see, e.g., DarboPeschanski 1987, 11; Fornara 1971a, 21, 23.

6. The terminus post quem for the publication of the Histories as a whole is 430 в.C., the time of the latest datable event mentioned in the work (7.137). On the basis of more indirect internal evidence and echoes of the Histories in other texts, Fornara (1971b;1981) argues for a publication date close to 414 B.c. Cobet (1977) favors the more orthodox date of ca. 425 в.C. The composition and dissemination of Herodotus' work must in any case have stretched over a number of years; see Evans 1991, 90. My argument does not depend on precise dating after 430 в.C., but I will briefly revisit the issue in chap. 3, "Divine Communication."

7. I am modifying for the sake of simplification a more subtle parallel made by Fornara (1971a, 40). 
affected by later developments and by the momentous political circumstances and ideological trends of his own time. In the case of Herodotus, observes Fornara, the interpretation of the past in light of the present is merely implicit: he only infrequently mentions the historical developments in Greece after 479 and even eschews many opportunities to do so in the course of his narrative. This is remarkable in an author who is so interested in complete historical processes that he habitually jumps backward and forward in time to show how a story began or how it ended. What we have at several points, then, is evidence of a deliberate silence about recent history and present circumstances, coupled with an ironical intent in the report of earlier events. ${ }^{8}$ Herodotus' narrative capitalizes on the audience's knowledge of how things turned out and draws its force and meaning from those later outcomes.

By describing a narrative of the past shaped by the circumstances of the present, Fornara draws us toward envisioning the Histories as a work that, through the narrative of their recent past, communicates to the Greeks (Herodotus' implied audience) things they should learn about themselves. ${ }^{9}$ This is, after all, a traditional role of historical or mythical narratives documented elsewhere-in the speeches of Homeric heroes, Pindar's epinician does, or the funeral orations of Athens. None of the narratives told by speakers in the Histories claim any other goal or effect, such as entertainment or pleasure. ${ }^{10}$

It is in conjunction with this didactic character of the Histories that I wish to explore the role of the ethnographic descriptions. These occupy a considerable portion of the narrative, yet Fornara excludes them from his argument about the relevance to the work of the historical and political circumstances of Herodotus' time. In his view, the history of the Persian Wars, particularly the last three books of the Histories, are one thing,

8. See Fornara 1971 b, 152-53. All Herodotean references to events after 479 в.c. are listed and discussed in Cobet 1971, 59-78.

9. See Fornara 1971a, 75-91; Raaflaub 1987; Corcella 1984, 186-235; Munson 1988; Stadter 1992; Moles 1996. This direction of Herodotean scholarship is partially indebted to Strasburger 1955.

10. This is unlike the songs of Demodocus and Phemius or Odysseus' narrative in the Odyssey (1.325-52; 8.62-92, 266-369, 471-541; 11.333-476). See Marincola 1997b, 11. Although ancient readers emphasize the enchanting effect of Herodotus' narrative (see Dorati 2000, 33-47), the internal model for reading the Histories is provided, e.g., by the useful stories of Solon (1.30.4-5), Socles (5.92), and Leotychides $(6.86 \alpha-\delta)$. See Stadter $1992,781-82$; 1997. Within the narrative of the Histories, one audience who sets out to listen to a (musical/poetic) performance for the sake of pleasure is discredited (1.24.5). Cf. $6.21 ; 6.129$. 
while the ethnographies are quite another: they might as well belong to another author. I have no objection to Fornara's support of Jacoby's theory, for example, that the Egyptian section was composed earlier than most other parts of the work and that it bears signs of having been written as an ethnography and not at all for the purpose of occupying the place it now does within a history. To explain the composite nature of the work and in particular the stylistic peculiarities of book 2, it would help to postulate that Herodotus may have started his intellectual development by looking outward at exotic phenomena, before directing his gaze inward at the Greek world in his maturity-that he tended toward a synchronic approach before turning to a diachronic research of causes. ${ }^{11}$ But the Egyptian and other ethnographies have been interwoven with the historical sections in the extant work. ${ }^{12}$ In light of the insights inspired by Fornara himself about the message Herodotus conveys to his Greek audience about themselves, it is time to reconsider what this message is, whether it informs all of the Histories or merely certain parts, and whether the ethnographies dilute and put it on hold or contribute to it in the special way that is consonant with their genre.

The argument that the Histories communicate a teaching to a contemporary audience by means of narrative leads us to my second interpretive tool for reading Herodotus. This is offered by Gregory Nagy in his Pindar's Homer, a book that aims at explaining the common roots and parallel developments of different modes of discourse of distinct archaic and classical genres. Within this broader discussion, Nagy approaches Herodotus' Histories as a performance based on that same tradition of the ainos that became embodied in other types of performance: in the fables of Aesop on the prose side and in the poetry of Hesiod, Archilochus, Theognis, and Pindar.

According to Nagy, Herodotus' performance of historie is the prose counterpart of the ainos of Pindar's epinician odes. Both are authoritative speech acts with the power to convey explicit as well as implicit

11. See Fornara 1971a, 1-23. The distinct features of Herodotus' persona in book 2 are discussed by Marincola (1987). However Fornara's statement (1971a, 18-19) that book 2 differs from other parts of the work on account of "the utter absence of the moral or philosophical element" seems wrong to me.

12. As Drews (1973, 84-85) observes, the Histories only go to prove that Herodotus still had ethnographic interests at the end of his career. Drews' explanation, however, that Herodotus' descriptions of foreign peoples have the function of magnifying the Persian Empire and therefore the accomplishment of the Greeks in resisting its attack does not account for a great deal of ethnographic material in the Histories. 
messages. ${ }^{13}$ Pindar places the here and now of the athletic victory in direct relation with the heroic achievements of the past by conferring epic kleos (renown) on the members of a privileged group within the aristocratic class of his time. At the same time, he also implicitly warns about the impending danger of degeneration of the aristocracy itself and of the consequent rise of a tyrant in the polis. ${ }^{14}$ The Histories of Herodotus, for their part, deal centrally with a relatively late historical past and do so more ambivalently than Pindar treats his paradigmatic time of heroes. The sociopolitical composition of the implied audience, the ideological stance of the text, and the specific substance of the message it conveys differ in many important respects from their counterparts in Pindar. But the past and the present, the explicit and the implicit, praise formulated in terms of kleos and warning about the threat of tyranny for the state, and a message of certain retribution for hubris based on the moral ideology of Delphi are all part of Herodotus' discourse, as they are of Pindar's. ${ }^{15}$

Nagy's parallel between Herodotus' historie and the ainos dovetails with Fornara's and Raaflaub's insistence on the relevance of the historical context of Herodotus' time to the narrative of the Histories. ${ }^{16}$ Herodotus' deliberate silence concerning events closer to his own time, emphasized by Fornara, is suitable to the implicitness of the ainos, to the obscurity of the related tradition of oracular poetry, and to the position of an author who is advising a politically diversified public about sensitive contemporary issues. ${ }^{17}$ The approaches of both Fornara and Nagy have provided foundations to my understanding of the Histories as a speech act bearing advice and warnings that address the present attitudes and behavior of the Greek cities toward one another and their future prospects.

From the point of view of Nagy's analysis, our initial question about the role of the ethnographic material in the Histories becomes, To what use has the genre of Greek ethnographic writing been put as part of a

13. Nagy $1990,215-338$, followed by Payen $1997,62-74$.

14. The features of the ainos of Pindar are described by Nagy (1990, especially 146-51, 164-66, 173-74, 181, 186-87, 192-99).

15. For the parallel between the mode of discourse of Herodotus and that of Pindar, see Nagy 1990, 215-338.

16. Fornara 1971a, 75-91; Raaflaub 1987; Nagy 1990, 305-16. Nagy characterizes Herodotus' narrative about Croesus the Tyrant as "an ainos which applies to Athens" (309).

17. See Nagy 1990, 332-35 for the element of ainigma (riddle) in the ainos and for the connection between Herodotus and the ainos, on the one hand, and wisdom and oracular poetry, on the other. 
discourse analogous to the ainos? One sign of adaptation of ethnography to the mode of the ainos in Herodotus is perhaps the one and only quotation from Pindar to be found in the Histories, the gnomic statement "custom is king of all" (3.38.4). Herodotus twists it out of its Pindaric meaning and gives it his own, precisely to use it as an interpretive bridge between his historical narrative about a hybristic king and his entire ethnographic project of describing customs. Moreover, in his polemical essay On the Maliciousness of Herodotus, Plutarch attributes to Herodotus the unitarian agenda of praising the barbarians and criticizing the Greeks and accuses him of doing so "deceitfully." 18 Later on, we will have other opportunities to test the extent to which Plutarch's rather pedestrian view can be credited. For the moment, we should notice that what he calls "deceit" is related in part to Herodotus' speaking obscurely through the narrative of the past, the words of oracles, and the representation of foreign peoples. In reference to a particular passage, Plutarch says that Herodotus there uses the Pythian god as his mouthpiece just as at other times "invents words and assigns them to Scythians, Persians, or Egyptians in the way that Aesop assigns his to ravens and monkeys." Since Aesop's fables are ainoi-narratives whose implicit, often political teaching could be understood from the context in which the author performed them-Plutarch's assertion confirms Nagy's argument about the analogies between Herodotus' discourse and that of the ainos. ${ }^{19}$

Although the discourse of Herodotus feeds on the same traditions and assumptions that govern the ainos, Nagy rightly insists that its essential component is historie, "inquiry." This is the process (and the product) of collecting evidence by seeing what is possible to see and by hearing the

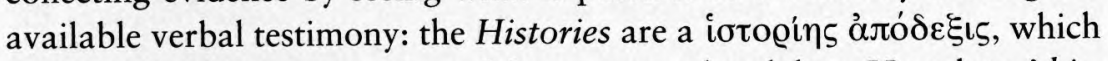
means the public presentation of those accumulated data. Herodotus' historie is a "scientific" undertaking, but it is also comparable to the process of inquiry in cases of judicial arbitration. ${ }^{20}$ In an inquiry of arbitration, the evidence collected serves as the basis for a judgment about who is right and who is wrong in a dispute and for the recommendation of a settlement on

18. See especially Plut. De Malign. Herod. $12-14=$ Mor. 857 A-F.

19. Plut. De Malign. Herod. $40=$ Mor. 871 D. Concerning this passage and the connection between Herodotus and Aesop, see Nagy 1990, 322-26, with evidence from the Life of Aesop on the context in which Aesop told his fables. See also Payen 1997, 69, 71.

20. See Nagy 1990, 315-20, for the bistorie of Herodotus as a juridical process in the light of attested cases of arbitration between Greek states. On Herodotus' scientific attitude and rhetoric, see Lateiner 1986; Thomas 1997; Thomas 2000. 
the part of the arbitrator or histor. In a similar way, the information presented in the Histories counts as evidence in view of judgments and recommendations by the histor Herodotus. ${ }^{21}$ The dispute is ultimately that among the Greek city-states in the time of Herodotus himself. The judgment and the recommendation represent the message of the Histories as a whole. This is communicated for the most part implicitly, through evidence that is both ethnological and historical.

\section{Assyrian Boats and Other Particulars}

The discussion of Greeks and barbarians that pervades Herodotus' work is based on a dialectic between traditional notions of the Greeks, on the one hand, and Herodotus' more or less overt disruption of these notions, on the other. Though recent scholarship has enhanced our understanding of Greek ideology about the barbaroi, it has not paid sufficient attention to the extent to which the several sources that constitute our evidence for this ideology respond to it in particular ways. ${ }^{22}$ Drawing from a generalized perception partially disseminated through poetic texts and owned, as it were, by his audience, Herodotus lures his modern readers into a false sense of recognition, only to undermine it. Though he represents otherness according to culturally determinedone might say, unconscious and inevitable-patterns of thought, he devalues its familiar implications through a series of concomitant strategies. He occasionally sets up the other as a model of what the Greeks would consider appropriate behavior; he complicates knowledge to both confirm and confuse ideological stereotypes; or he counterbalances his representation of difference with indications of unexpected similarities between his ethnographic subjects, other groups of barbarians, and different groups of Greeks. ${ }^{23}$

Herodotus' ethnographies are thematically unitarian descriptions, each discussing the customs, geographical situation, and historical traditions of this or that people. They are made up of particulars, which contribute to a

21. The juridical meaning of histor is explained by Nagy $(1990,262,315-20)$. See also Connor 1993. Dewald (1987) applies the term to Herodotus for the sake of a different distinction: to indicate the narrator and implied author of the Histories as he emerges from the work (on narrator, implied author, and real author, see Booth 1983, 67-77; Chatman 1978, 147-58; Genette 1980, 213-14).

22. See, e.g., Hartog 1988, xxiii; Rosellini and Saïd 1978; Hall 1989.

23. See Pelling 1997. 
general representation of the people in question but also possess a measure of autonomy separate from the monographic section to which they belong. ${ }^{24}$ The uncertainty about the role of ethnography in the Histories arises again and again from many individual ethnographic details, posing each time a series of typical questions: What is the meaning of this feature? How does it contribute to characterize a given ethnic group? In what other ways does it relate to its ethnographic surroundings or to any other part of the work? Examining Herodotus' discussion of the boats of the Assyrians (1.194) will provide a preliminary demonstration of the value of particulars as evidence in the political discourse of the Histories.

In the phrase that introduces the description, "the greatest wonder to me in that land, after the city itself" (1.194.1), the city is Babylon. Herodotus has discussed it earlier, right after the narrative statement that Cyrus, having subdued many other peoples of Asia, now planned to conquer it (1.178-87). Babylon is an architectural marvel, defined by its river and bearing the stamp of royalty. Surrounded by a double circle of walls, it stretches on both shores of the Euphrates, with one of two symmetrical structures rising at the center of each half: the sanctuary of Zeus Belos and the royal palace (1.178-83). Babylon has been built and adorned by its rulers. The two clever queens whom Herodotus singles out

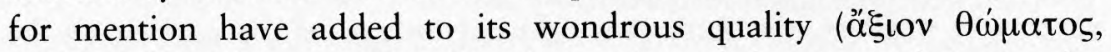
1.185.3; $\alpha \xi\llcorner\circ \theta \varepsilon \dot{\eta} \eta \alpha, 1.184)$. One has endowed the city with impressive dikes to prevent flooding. The later one, Nitocris, has detoured the course of the Euphrates by means of canals to the north and an artificial lake, to protect Babylon from the Medes. By draining the waters of the river into the lake and letting them flow back again, she also built across the Euphrates a bridge that connects the two sides of the city in daytime and is removed at night to prevent crime (1.184-86).

The already announced narrative of Cyrus' campaign against Babylon resumes after the description of the city. Accompanied by mule-drawn wagons carrying royal food supplies and the drinking water of his native Choaspes River in silver vessels, the Persian king crosses another stream, the Gyndes, which he divides into 360 channels in punishment for drowning one of his sacred white horses $(1.188-89)$. Water and mighty walls seem to make Babylon impregnable. Cyrus, however, turns the hydraulic works of Nitocris to his own advantage: he drains the Euphrates into the artificial lake she had built and invades the city through the riverbed.

24. See Darbo-Peschanski 1987, 138-39. 
Distracted by festive pleasures, the Babylonians do not see him coming, and the city falls into Persian hands (1.190-92.1).

The campaign narrative is followed by another, more properly ethnographic description, this time of the Assyro-Babylonians and their land. This description begins by listing the resources the newly conquered province added to the Persian Empire, amounting to a third of those provided by Asia as a whole (1.192). A chapter on agriculture (193) explains this fabulous wealth: a hand-operated irrigation system makes Assyria the most fertile of lands. Cereal plants grow to unbelievable proportions. Oil is derived from sesame, and the palm trees yield a fruit used to make food products as diverse as bread, wine, and honey.

Here, the boats carrying the merchandise down the Euphrates are introduced. In the various sections in the ethnohistorical Babylonian narrative so far - the description of the city, the account of Cyrus' campaign, and the Assyrian ethnography - dealing with the river has been a test of sophie (cleverness) by which all the protagonists are evaluated, either implicitly or explicitly: the rulers of Babylon used the river to increase its safety and order; the foreign king Cyrus conquered Babylon by means of waterworks; the careless city dwellers let themselves be caught unprepared; unspecified people authored the irrigation system; and finally, when we reach our passage, the Assyrians take advantage of the current of the Euphrates for their journey from Armenia to the markets of Babylon. These merchants mark a transition from royalty to the society whose customs are then described in areas of culture common to all nations around the world-dress, marriage, health care, funerals, and religion. Sophie remains intermittently a factor (see $1.196 .1 ; 1.197$ ), down to the report of the peculiar Fish Eaters, who, as the other natives do with palm dates, are able to process a single ingredient into various forms (1.200).

Like all texts, this narrative and descriptive section is intersected by a number of different and partially overlapping cultural codes or subcodes. ${ }^{25}$ As a resource or an obstacle, the river is not merely a term of the

25. On the notion of "codes," see Barthes 1970; Munson 1991. The primary code of any text is the linguistic (English, Greek, etc.). Second- or third-order cultural codes (more properly called "subcodes") are represented by the words and ideas used when speaking about something: in a typical nineteenth-century fictional text, e.g., Barthes $(1970,18-20)$ identifies a proairetic code (code of action), a hermeneutic code (signaling the existence of a mystery or progress toward its resolution), a semic code (or code of connotation), a symbolic code, and an indeterminate number of cultural codes that communicate by making reference to a certain body of cultural knowledge shared by the implied audience (e.g., the terminology of a medical textbook will constitute in effect a special language, a technical medical code). 
codes of action, geography, and military strategy but also a symbol of what is given, one's proper share, or that which delimits it. ${ }^{26}$ It participates, in other words - as is frequently the case with concrete features in Herodotus' narrative-in the symbolic code of the text. ${ }^{27}$

In relation to the river, another code emerges, that of kingship, and the actions of kings also acquire symbolic meaning. ${ }^{28}$ Characteristic of both native and foreign rulers in the Assyro-Babylonian section is a control over the natural environment, a control that appears morally problematic and therefore dangerous. Cyrus' royalty is defined at the outset by his ownership of the water of the Choaspes, which he and all Persian kings carry around for their own special use wherever they go (1.188). Cyrus' emasculation of the Gyndes corresponds at long range, backward and forward, to all the instances of expansionist violations of rivers in the Histories. The first of these occurs when Croesus initiates war against Cyrus and crosses the Halys, which some say he split into two streams (1.75). The last are represented by Xerxes' abuse of the Hellespont (7.35) and by the advance against Greece of his large Persian force, which drinks rivers dry. ${ }^{29}$ Unlike the violations of Croesus and Xerxes, Cyrus' assault on the Gyndes has no negative results. When he drains the Euphrates and captures Babylon and its wealth, his cleverness is crowned with success. Ethically, however, his conquest is on a continuum with two later royal thefts by Darius and Xerxes, mentioned in the same narrative $(1.187,1.183 .3)$. Cyrus himself will meet with an unfortunate end in due time, after crossing another stream, the Araxes, in his attempt to subjugate the Massagetae (1.208).

26. Croesus' crossing of the Halys involves an attempt to acquire land beyond his $\mu$ o $\varrho \alpha$, "share," (1.73.1). The symbolic interrelation of physical and moral boundaries in Herodotus is discussed by Lateiner (1989, 126-44). See also Immerwahr 1954, 19-28; Immerwahr 1966, 325; Konstan 1983; Stadter 1992, 785-95; Payen 1997, 138-45.

27. Physical objects as conveyors of meaning in Herodotus are discussed in Dewald 1993. On the symbolism of metals, see Kurke 1995. Symbolic action in Herodotus is discussed by Payen (1997, 29-31 and passim). Any word or narrative element in a text normally belongs at once to many different codes and to codes within the codes (e.g., the word heart belongs to the codes of love, physiology, medicine, cardiology, etc.). The symbolic code draws terms from overlapping codes and helps to reshuffle and reassign them to yet other codes. So in Herodotus, the river becomes, through the symbolic code, a part of the political code and the code of ethics, the languages in which we talk about such issues.

28. The actions and features typical of kings (i.e., all the terms of the "monarchical code") are also terms of the symbolic code when they not only apply to real kings but become the means for talking about, for example, the human condition and human actions in general. See chap. 2, "Analogy as an Interpretive Tool."

29. See 7.21.1, 7.43.1, 7.58.3, 7.108.2-109.1, 7.109.2, 7.127.2. There are twentyfive rivers mentioned in the account of Xerxes' march from Critalla to Thessaly alone (7.26-131). 
The digging, draining, and bridge building of the Babylonian queens have more benign motives and do not entail trespassing into someone else's land. These acts also represent, however, monarchic imperialism over the environment. Like Nitocris' attempt to impose order on Babylon from above, these acts are useless given the citizens' lack of discipline and prove counterproductive in the face of the enemy attack.

The folks whom Herodotus describes as making their living through the river have neither leisure for lapses nor monarchic opportunities to exercise intrusive mastery on earth and waters. The boats of Assyrian merchants are constructed of inexpensive materials (timber, hides, and straw), which are then recycled and reassembled. Unlike royal masonry work, they do not mark the land. To some extent, like the leather trousers of the Persians of long ago (1.71.2), they connote primitivity. ${ }^{30}$ They are crude in shape, all round, with no stern or prow. More "like shields" than like ships, reactive rather than offensive, they are designed not to cross the seas, to be steered in different directions and against the waves, or to dominate the elements but to drift downstream helped along by paddles. Very large or less large, they only require a crew of two men. Once in Babylon, the merchants sell their wares and the framework of their boats, then retrace their way by land on their donkeys, because the swiftness of the current prevents them from sailing back upstream. They display not only industry and sophie but also what we call common sense and the Greeks would include in their notion of sophrosune. ${ }^{31}$

The description of the collapsible boats and other details in the ethnography characterize the Assyrians in a way that on the whole tends to redefine the issue of difference: though their boats are peculiar, their market of brides preposterous, and their diet exotic, a talent for problem solving makes the Assyro-Babylonians similar to the Greeks. Sophie is a virtue the Greeks claimed to possess to a higher degree than all barbarian nations (see, e.g., 1.60.3). To counteract such ethnocentric assumptions by means of specific evidence and praise is an important goal of Herodotus' historie.

30. Connotation, activated through signs or indices (the semic code: cf. n. 25), is closely akin to symbolism but involves a more immediate and less constructed connection between signifier and signified. See Barthes 1970, 6-9, 19; Prince 1987, s.v. "seme."

31. See Geertz 1983, 71-93, on our tradition of regarding common sense as a transcultural category ("what anyone clothed and in his right mind knows"). On sophrosune, see North 1966, especially 28, where North notes that although Herodotus uses sophr-words sparingly, he "is the most fertile source in Greek prose of stories illustrating traditional ideas of sophrosune." 
At the same time, however, Herodotus' particulars often appear, as in this case, to have less to do with the construction of the national identity of a foreign people than with projecting onto a faraway setting pieces of a problematic that is entirely Greek. One well-known ideological contradiction in the mid-fifth century was that of the simultaneous desirability of exceptional (i.e., symbolically "royal") status and normal (or citizen) status, as is illustrated in the Histories, for example, by the contest of happiness between Croesus of Lydia and Tellus of Athens. ${ }^{32}$ Throughout Herodotus' work, the representation of the otherness of foreign peoples competes with the representation of the cross-cultural otherness of kings. By setting the pragmatics of everyday life, exotic but legitimate, side by side with the behavior of the powerful agents of history, his ethnographies represent a crucial part of a discourse at once "democratic" (almost in the modern popular sense of the word) and anti-imperialistic. To the talking Scythians, Persians, and Egyptians whom Herodotus uses, according to Plutarch, for saying what he wants to say, we may here add the silent Assyrians. The description of their boats, like the ainos of Tellus, provides a foil for the actions of kings.

The ethnographic style of the Histories, in the Assyro-Babylonian logos and elsewhere, consists mostly in the factual description of particular features, with little interpretation of their meaning. What has been characterized as Ruth Benedict's typical mode, the general description of a people's worldview, repeated again and again and illustrated by examples of what they do and say, is in general alien to Herodotus. ${ }^{33}$ In the Histories, the point of what "they" do and the reasons why "we" should find it interesting have to emerge from the description of what they do. The near absence of explicit interpretive commentary fits the tradition of Greek ethnographic writing as well as Herodotus' mode of implicit communication. In the case we have examined and several other times in the Histories, celebration of the subject stands in lieu of interpretation. The initial sentence of the passage communicates to the recipient of the narrative that the feature is important or, in other words, meaningful. The phrase "great wonder" $[\theta \tilde{\omega} \mu \alpha \mu \dot{\varepsilon} \gamma\llcorner\sigma \tau o v]$ establishes its membership in the broad category of "achievements great and wonderful, some performed by Greeks, some by non-Greeks," that, according to the first sentence of the

32. 1.30.3-5. On the Greek political and ethical discourse concerning tyrannical power, see McGlew 1993, especially 30-32, 196-212. On kingship as symbol, see my n. 28 in this introduction.

33. For the description of Benedict's style, see Geertz 1988, 108-20. 
work, are deserving of permanent renown. The researcher and narrator named in that first sentence, Herodotus of Halicarnassus, here comes into the open-with "the greatest wonder to me"-to claim the inclusion as his own idiosyncratic choice. When he says, "the greatest wonder to me after the city," he creates a paradox and helps to establish at the outset the symbolic nexus between two discrepant items, "leather boats" and "Babylon," the people and their kings. This is, on the whole, a more eloquent directive than simply a red mark on the page. It is almost as eloquent and interpretive, in an implicit way, as the famous title that announces one of Ruth Benedict's ethnographic inquiries, The Chrysanthemum and the Sword. ${ }^{34}$

\section{The Histories as Performance}

Announcements and glosses such as the one we have just considered signal the presence of the one who is telling the story and his reactions to it. They represent the metanarrative component of the discourse, the study of which is a tool for better understanding the message, ideology, and tone of a text. In the case of Herodotus, the metanarrative often enhances our awareness of a direct verbal communication from a speaking author to a listening audience. The Histories as we have them are obviously a written text, and they contain internal signs of writing as a tool of composition and publication..$^{35}$ These signs are less conspicuous, however, than those indicating or imitating an oral situation for Herodotus' speech act. ${ }^{36}$ As Nagy maintains, the work is "not a public oral performance as such," but it is nevertheless "a public demonstration of an oral performance, by way of writing." 37

34. Benedict $(1989,2)$, with characteristic explicitness, explains her title: "Both the sword and the chrysanthemum are part of the picture. The Japanese are, to the highest degree, both aggressive and unaggressive, both militaristic and aesthetic, both insolent and polite..."

35. Examples are the authorial "I write" occurring side by side with "I say" in programmatic statements (see chap. 1, "Types of Introductions and Conclusions" and "SelfReferential Glosses"); long genealogies and catalogues (see Thomas 1989, 189; Harrison 1998); perhaps the past tense in metanarrative sentences of the type "it could be seen still in my time" (see Rösler 1991); and, of course, the statement in the first sentence that Herodotus intends to preserve the glory of great deeds and save them from oblivion.

36. See Pohlenz 1937, 208-11; Lang 1984, especially 1-17; Munson 1993a; Stadter 1997.

37. Nagy $(1990,220)$ so argues on the basis of the first sentence. For the notion of performance applied to the Homeric poems, see Martin 1989, 1-42. We do not, of course, 
We have some external evidence, more or less direct, of historical Herodotean performances. ${ }^{38}$ Our written text may theoretically stand in relation to these as a special version of a larger potential performance, a reservoir for potential performances, or a collection or summary designed to extend the life and usefulness of actual or possible contemporary performances. Since I approach the Histories in this way, considering it a text that is unitarian but not definitive, I will not emphasize its overall structure (each narrative in the exact place in which it stands) and integrity (the original presence of all the narratives it now contains) as primary conveyers of meaning. ${ }^{39}$ Thematic and factual cross-references so multifariously pervade the work and spill over onto the unmentioned real world of Herodotus' audiences that, to communicate its message, a given narrative may relate in fairly specific ways to the immediately surrounding narratives though it is not entirely dependent either on them or on what is now the whole. The narratives of the Histories have the potential for joining up with many other narratives that are now far away or simply not there at all. Like the Assyrian boats, Herodotus' Histories lend themselves to being disassembled and reassembled into smaller (or, theoretically, larger) functional wholes.

The apparent elasticity of the Histories recalls to some extent the circumstances of rhapsodic performances of the Homeric texts in classical times. It is also internally indicated by their relative open-endedness, by the unfulfilled promises they contain of narratives that could have been included but are not, and by the contrived and not inevitable character of many of the transitions between narratives. ${ }^{40}$ The one and only

postulate the same sort of orality for the Histories as one may for the composition of the Homeric poems. But see the parallel drawn in Murray 1987, 107. Most importantly, Herodotus' use of writing at a moment of transition between preliterate and literate conditions does not entail a widespread readership from the beginning, and an audience of listeners is more likely. On the related issue of literacy, reading, and the aural reception of literature in the fifth century B.C., see Davison 1962; Flory 1980; Havelock 1982, 146-47; Thomas 1989, 15-34.

38. See Plut. De Malign. Herodot. $26=$ Mor. 862A-B (= Diyllus, FGrHist 73 F 3); Lucian Herodot. 1-2; Marcellin. Life of Thuc. 54; Eus. Chron. Olymp. 83.4. This evidence is rejected by Powell $(1939,31-36)$ and Johnson (1994). But see Parke 1946, 86-87; Momigliano 1978, 62-66; Evans 1991, 89-132; Dorati 2000, 17-52.

39. Structure has been emphasized by Wood (1972, especially 19) and productively studied by Immerwahr (1966). See, however, Immerwahr 1966, 308. I mean not to devalue the meaningfulness of the present structure but to suggest that other combinations of logoi would be just as meaningful.

40. On the end of the Histories, see Dewald 1997, with full bibliography on the previous scholarly discussion. On its unfulfilled promises, see Drews 1970 (discussing 
performance available to us, in other words, possesses a retroactive unity and also partakes of the incompleteness or fluidity of the various potential performances of which we can conceive.

As a display in front of an audience, the Histories are a "performance" in the ordinary sense of the word. They are also a "performance" in a narrower sense, from the point of view of speech-act theory. They represent an utterance that does something, performing a range of worldchanging operations. At the surface level, they inform, preserve the memory of events, and establish a record of praise and blame. Implicitly and at a deeper level, they predict, advise, warn, attempt to persuade, or promote a certain predisposition in the audience. ${ }^{41}$ The substance of these implicit predictions, advice, and warnings represents, once again, the message of the work.

The various functions (or illocutionary acts) that the Histories perform at different levels through the narrative are facilitated by the metanarrative. Narrative statements (whether recounting or descriptive) are, theoretically, world-describing utterances: any other eventual functions they might perform (e.g., warning) are especially indirect and disguised. ${ }^{42}$ The narrative records what is real, simply because it is real. With the metanarrative, however, the author of the narrative emerges from the text. As an explicit mediator between reality and the audience, he communicates to the audience about his record of reality and its reason for being. ${ }^{43}$

1.106.2 and 1.184); Nagy 1990, 235 n. 91 (on 7.213.3). The artificiality of Herodotean transitions between different logoi is noted by Jacoby $(1913,343-46)$. Within modern (written) literature, an approximate parallel to the rhapsodic nature of the Histories is provided by what Genette $(1980,149)$ calls the "unity after the event" of Proust's À la recherche $d u$ temps perdu, a work made up of heteroclyte material that was being continuously rearranged and revised by the author even during the last stages of publication. See also Eco's (1962) definition and description of what constitutes an opera aperta and an opera da finire.

41. For the conjunction of the ordinary and speech-act meanings of the terms performance and performative, see Martin 1989, especially 5, 47. Speech-act theory was initiated by Austin (1962); for subsequent developments, see especially Searle 1976; Bach and Harnish 1979. Application of speech-act theory to works of literature is discussed by van Dijk (1976), Pratt (1977), Chatman (1978, 161-66), and Searle (1979, 58-75).

42. They are true-or-false statements, such as "Napoleon won the battle of Austerlitz" or "the earth is flat" (see Austin 1962, 132-49). In Searle's subsequent classification of five categories of illocutionary acts (1976), they are called "representatives."

43. The presence of the narrator as a more or less overt mediator of narrative statements (and his absence in "nonnarrated" narratives) is discussed by Chatman (1978, 146266). See also Genette 1980, 212-62; for Homer, see Richardson 1990, especially 1-8. For X Herodotus, see Dewald 1987, forthcoming a; de Jong 1998. 
Metanarrative signs are of course embedded in the narrative throughout. Narrative as pure transcript of the real world exists only in theory, because words can achieve exact mimesis of other words only, not of actions and states. ${ }^{44}$ But in Herodotus we are faced with an especially massive metanarrative component consisting of introductions, conclusions, and glosses that in some way summarize and explain the narrative ("X is like Y," "I will tell X," "X means Y," "I have finished with X").45 These statements stand out from minimally narrated narrative statements: Prince writes, "their appearance is similar to that of a (fragmentary) text in the text, representing a language that is other in the language of the text and establishing some of the interpersonal coordinates of a communicative situation." 46 Many contain a grammatical sign of the narrator (e.g., "the greatest wonder of all to me ... I am going to describe"), but others do not. Since they manipulate the narrative, they are also more likely to evaluate, convey advice, question, argue, promise, express the narrator's state of mind, and even bring a state of affairs into existence (e.g., convict)-in sum, to reveal purposes that go beyond simple representing or reporting. ${ }^{47}$

\section{The Contents of This Book}

Different types of metanarrative sentences are briefly classified in chapter 1 , which serves to establish the basic distinctions and terminology on which the rest of the analysis in this book is based. I then proceed to examine two overlapping functions pursued in Herodotus' discourse by narrative and metanarrative means: comparison and interpretation. The

44. Hence, although we say that nonnarrated narrative (reality recording itself) and even its closest approximation, minimally narrated narrative, are theoretically "mimetic," Plato uses the term mimesis only in reference to narrative in its dramatic form (Rep. 392d$394 \mathrm{c}$ ). In the case of a speech reported by a narrator in oratio recta, no mediation is visible between "reality" and the text. By contrast, actions require the mediation of a narrator, who puts them into words through the narrator's own discourse.

45. Dewald (1987, 148-50) compares Thucydides' narrative surface to "perfectly transparent glass through which one is encouraged to imagine one is directly perceiving the res gestae narrated" and argues that Herodotus' narratorial interruptions resemble rather "those little decals-flowers, rainbows and whatnot-scattered by the cautious on the surface of the glass."

46. This quotation, well suited to Herodotus' discourse, is part of Prince's description of metanarrative in general $(1982,127)$.

47. See, e.g., Herodotus' "conviction" of Ephialtes (7.214.3), discussed in my chap. 3, "Interpretation in the History." 
first of these crisscrosses the text in two separate directions: diachronically for the events of history and synchronically for ethnographic and other phenomena separated not by time but by space. Figuring out how each of the two types work and how they cohere with one another is the task in chapter 2 . Through the second and most encompassing function, interpretation, the text signals what facts mean and evaluates their worth. Here once again, history and ethnography go their separate ways. As I show in chapter 3 , the political message of the work depends on the cooperation between a relativistic ethnographer, who interprets little and evaluates cautiously, and an absolutist historian, who explains historical action in moral terms.

Herodotus' message is nuanced, communicated not without obscurity and even, despite the charm and lightheartedness of his style, a certain degree of effort. It requires that we bridge our distance from the intended audience to which it is directed by a painstaking analysis that will not, however, entirely protect us from interpretive risks. The opacity of the Histories partially results from the uneasy series of mediations on which they rely. What is far away in space and time serves to talk about the present of narration, but the burning issues of the audience's here and now are treated, as I have said, as almost unmentionable. Particulars not only communicate general principles but also provide contradictory evidence. Reality is represented through the narratives and arguments of sources and characters, some more reliable than others; the narrator often declines to unify the plurality of voices. ${ }^{48}$ Herodotus' use of the terms of the Greek/barbarian antithesis frustrates his project of subverting that antithesis and redistributing the criteria of otherness. Herodotus' attempt to reconcile the Greeks among themselves is based on a representation of a culturally special and homogeneous Greekness; yet this goal collides with his need to assign them to the shuffle of humanity, showing that they are almost just as different from each other as from non-Greeks. The instability and uncertainty of a logos that undermines itself as it goes along reflect the gaps and inconsistencies of the ideology to which Herodotus responds from within. They are also the mark of a historian who, if we will not find him unfailingly honest and objective, is still, in the way he displays evidence, more honest and objective than most. ${ }^{49}$

48. See Dewald 1987, 160-63, 167-70.

49. On Herodotus' early reputation for dishonesty or lack of seriousness as a historian, see Evans 1968. Some modern scholars deny both Herodotus' accuracy and the authenticity of his source citations. See especially Fehling 1989; West 1985; Hartog 1988, especially 
Herodotus' speech act stands at the intersection of the three fundamental kinds of discourse. Just as we can distinguish sentences that are declarative (impart knowledge), imperative (give orders), and interrogative (request information), so we can, on the basis of these categories, identify corresponding types of text..$^{50}$ As the exposition of the results of an inquiry and as a narrative of past events, the Histories conform to the declarative modality of discourse. I argue, however, that by virtue of its message, the work is also an imperative text: it "invites the reader to adopt a position of struggle rather than stability, specifically struggle in relation to something which is marked in the text as ... existing outside discourse, in the real world." But to the extent that the recipient of Herodotus' logos is caught up in contradictions and invited "to produce answers [the text] implicitly or explicitly raises," the Histories also constitute an interrogative text. ${ }^{51}$

The combination of the declarative, imperative, and interrogative modalities in the discourse of Herodotus' Histories is inscribed in the recurrent concept of thoma, "wonder," which is the topic of chapter 4. Appeals to wonder belong to the celebratory function of the text, and "a wonder" is a fact that wants to be narrated-incredible if true, hard to imagine if unknown. The narrator shares it as information, demands a reaction, and leaves us wondering what it means for our understanding of the Histories. With the term thoma, the text legitimizes the question that listeners and readers are bound to ask about any other apparently optional fact included in the Histories: why is this here? Since thoma words advertise onetime occurrences, lasting individual achievements, geographical features, and cultural artifacts, an exploration of their meaning will throw further light on the ability of metanarrative to bridge the distinction between ethnography and history.

364. Cf. Pritchett 1993; Fowler 1996, 76-80. My work investigates meaning rather than factual truthfulness; an investigation of the meaning Herodotus attributes to facts he narrates would be even more urgent if he had invented them rather than seen or heard them. In practice, however, I believe that Fehling and others have not proven their case and that the gulf between the narrator and the real author is not that wide; see the more subtle proposal by Marincola (1997b, 14-19). The dishonesty of Thucydides for the sake of advocacy is a newer issue. See Badian 1993, 125-62; cf. Hornblower's narratological discussion of Thucydides' rhetoric in presenting the evidence (1994a). See Moles 1993.

50. See Benveniste 1971, 110, quoted by Belsey $(1980,90)$.

51. See Belsey 1980, 91-92, for the definitions quoted. 